BOGDAN BURLIGA (D), MICHAŁ MAUKS (D)

UNIVERSITY OF GDAŃSK

\title{
AN INSTRUCTIVE STORY ABOUT HOW A BYZANTINE PRINCESS BRAVELY LOOKED DEEP INTO THE ABYSS OF OBLIVION
}

for Bożena and Wiestaw Dobosz

ABSTRACT: Anna Comnena's beginning of the Prologue to her Alexiad is a fine literary and rhetorical piece. It is about the problem how destructive the passing of time is, and for which the only obstacle can be to consolidate the achievements of the past in a literary work. Such a line of thought was usually interpreted in the terms of the author's rhetorical topos. Most frequently, this topos occurs in ancient historiography whose formal features were continued by Greek historians of the Eastern Roman Empire (Byzantium). While not deyning that there is much to recommend in such an approach, the present paper tries also to pay attention to Anna's life and stress the authenticity of her emotions. In this light the Preface to the Alexiad, while remaining an example of magnificent rhetorical argumentation, can also be seen as an authentic attempt 'to stop' time, an attempt made by an aging woman, conscious that this is the only chance to give meaning to her own life by preserving it in the memory of future generations, so, in a sense, to 'immortalize' it, given that it will be told in a written story, capable of surviving in time.

KEY WORDS: Anna Comnena, Byzantine historiography, prologue, topos, time, memory, oblivion 


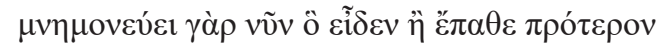
(Aristotle, De memoria et reminiscentia, 451a 30)

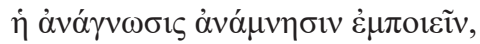

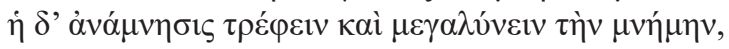

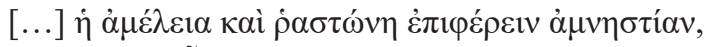

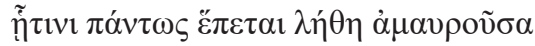

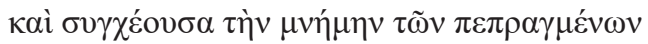
(Joannes Scylitzes, Syn. hist. praef. 1. 50; ed. J. Thurn)

It is doubtful whether Gaspar Noé, an acknowledged (and controversial, for many critics) French film-maker, had ever had the great historial work of the Byzantine princess Anna Comnena in mind when writing the script of his notorious feature movie Irréversible (2002). Such a supposition and association of the two works, from different times and of a different nature, may seem odd, immediately raising the question as to what do they have in common at all? You're right, nothing, mostly and essentially. Nothing except for one thing, however. The reason is because the very final lettering (the first chronologically), in Noé's highly pessimistic and depressing film runs: Le temps detrouit tout.

For any student of classical literature and thought, familiar enough with ancient Greek and trained in Roman philosophical legacy, these words will sound probably as if they were taken, say, straight out of Heraclitus' '̌ $\pi \varepsilon \alpha \pi \tau \varepsilon \rho o ́ \varepsilon v \tau \alpha$, or, even better, Marcus Aurelius' Meditations that is an exposition of Stoic doctrine, from our point of view full of nihilistic observations about the futility of life and human existence. But, as noted before, leaving aside the emperor Marcus' famous credo of Roman Stoicism, the sentence from Noé's movie has been anticipated - astonishingly - in the Preface to another magnificent literary achievement that certainly remains a unique medieval Eastern Roman document of the $12^{\text {th }}$ century: the Alexiad of Anna Comnena. ${ }^{1}$

\footnotetext{
1 On this aspect see Ljubarskij 2000: 169; for thoughtful general introductions see Jurewicz 1984: 226-233; Neville 2018: 174-185; also instructive is Herrin 2009: $277-287$.
} 


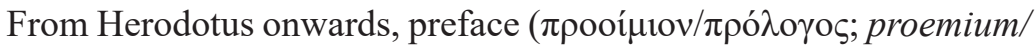
exordium) was a traditional trait of ancient and medieval historical works. ${ }^{2}$ In Anna's history it precedes a truly epic narrative. Written in a fine Atticism, ${ }^{3}$ that learned 'Kunstsprache' 4 of the princess 'born and

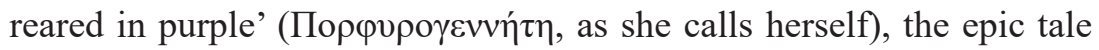
is an encomiastic memory, ${ }^{5}$ reviving a fascinating narrative of the ascendance to power and, then, the reign of the author's beloved father, Emperor Alexius (I) Comnenus (1081-1118). So we get the story of a great statesman in the times of crisis, ${ }^{6}$ who saved the state weakened during long years of stormy political upheavals between 1025-1080. ${ }^{7}$ As it is known today, for the further fate of the Byzantine empire the reign of Alexius was to be an eventful, indeed decisive period. Today, his reign remains the focus of an enduring scholarly interest, mainly because of the appearance of armies of Western baronry and nobility in the territory of Byzantium, ${ }^{8}$ - a phenomenon that began a centuries-long, socio-political-religious movement, commonly known as the Crusades.

2 See the still valuable study of H. Lieberich (1899). On Latin introductions see Janson 1964. Other prologues to technical treatises are collected in Santini, Scivoletto 1990.

$3 \quad$ See Horrocks 1997: 175-178.

4 Reinsch 2001: 15. Here we omit a controversial suggestion made by J. HowardJohnston (1996: 285-288), claiming that the unnamed co-author of the Alexiad was Nicephorus Bryennius, Anna's husband (Alex. praef. 3, 1) and the author of Material

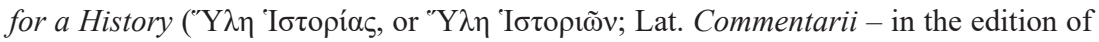
F. Meineke); cf. Howard-Johnston 2018 (esp. 490-492); but see Macrides 2000.

$5 \quad$ Alex. XIV 7, 1-4; cf. Alex. IV 8, 1, with Neville 2014: 268. Paul Magdalino (2012: 220), recalling the critique that Joannes Scylitzes directed towards the historians who praised (or blamed) authorities and emperors, adds that to Anna's work that is 'almost hagiographical' belongs the same category. On Anna's 'filial piety' towards her father see Dölger 1966: 231.

$6 \quad$ Cf. Alex. III 9, 1; see Treadgold 2013: 366; cf. Angold 2004; cf. recently Frankopan 2017: 181 .

On Alexius' reign see generally Chalandon 1900; cf. also Ostrogorsky 1989: 365375; Vryonis Jr. 1967: 134-135; see also Jurewicz 2005: V-XXII; Lauxtermann 2017: $1-2$.

8 Modern accounts of the First Crusade abound. A standard treatment still remains Runciman 1951, to be read with Riley-Smith 2003. For a Byzantine point of view see, among others, Charanis 1952; France 1983. See also Kazhdan 2001, and recently Harris 2014. 
Undertaken to regain the Holy Land from the Seljuk Turks, ${ }^{9}$ this prolonged venture, still a hot topic among modern scholars, had a profound influence on the fate of the Eastern Roman Empire, ${ }^{10}$ especially in light of what happened in $1204,{ }^{11}$ that is, about 60 years after the old princess Anna, living in for many years political isolation at a monastery, told the story of her life.

It goes without saying that the work of the 'purple-born' Anna remains a sine qua non-reading for every medieval historian and historian of literature, especially of the Eastern Roman Empire. Retaining a 'Homeric' flavor, ${ }^{12}$ this colourful and entertaining ouvre is a mine of information, rich in priceless historical details. ${ }^{13}$ As mentioned above, it is mainly the Preface to her work that will be the object of our interest here. But to be even more precise, it is not the whole Preface but its very short beginning, that is, what constitutes $\S 1$ in the modern editions of the text. The main reason is that it brings forth general, philosophical remarks on time but not so much - in the fashion of Saint Augustine - what time is. ${ }^{14}$ Instead, what concern us here is her anxiety on how devastating time is to famous achievements and noble deeds of people - if they are not preserved ('fossilized') in people's memory, by means of the art of writing.

9 Cf. Zakrzewski 2007: 266-267. Anna's tale of the appearance of the Western barbarians in Byzantium is contemptuous, hostile and biased, of course, cf. Alex. XIV 4, 3, where she simply sees the 'Celts' as mere invaders; also Alex. XIV 7, 2; see esp. France 1994: 111-112, 144-145; Frankopan 2001. Modern experts stress, however, that despite the fear of the Byzantine elites, mutual distrust and animosities between them and Latins that led to open conflict near the imperial capital and at its gates (described in detail by the princess who complains about barbarity of the 'Celtic' hordes), the marching Crusading army repulsed the Turks and Alexius was able to restore succesfully imperial authority over Asia Minor; see Geanakoplos 1984: 9; also Haldon 2000: 43.

10 Phillips 2019: 102; cf. Frankopan 2012: 42f., and Savvides, Hendrickx 2001: 94.

11 Cf. Cameron 2014: 7-25.

12 Cf. Buckler 1929; Kazhdan 1991: 1142; Kaldellis 2010: 219.

13 As Sir Runciman rightly wrote (1966: 245), 'for all her elaboration and self-consciousness remains the greatest of women historians'.

14 Conf. 11, 14 and 28. But taking it generally, an observation made by P. Brown in his seminal Augustyn z Hippony (1993: 163) that the Confessiones are imbued in running of life ('life runs through it', p. 158 of the English 2000 edition) is true, all differences notwithstanding, in the case of the Alexiad, too: to a great extent, Anna's history is also a meditation on the passing of time (see below.) A good introductory book still remains Levi 2018, although he does not deal with Augustine; also Nikulin 2015. 
Being as far as possible from the claiming that this part of Anna's Preface - its true 'introductory'section, so to speak - has no rhetorical nature or connection with the rest of it, we would suggest, nevertheless, that her introductory opening section remains a unique and exceptional kind of reflection in which the writer's affecting consciousness of the passing of time reveals something more than a deep knowledge of literary tradition and plausible handling of the sources. ${ }^{15}$ On this ground it is worth spending a few words on the opening sentences. Thus, in what follows, first some comments will be devoted to Anna's complaining about the lapse of time as a literary $\tau$ ó $\pi \circ \varsigma,{ }^{16}$ which was by no means identical with the typical Western medieval expression of woe, that notorious sic transit gloria mundi-lamentation. Subsequently, we will treat 'rhetoric' not as a clever strategy in a text but a highly emotional, full of personal remarks, ${ }^{17}$ indeed very moving testimony of (let's say it honestly) a tragic experiencing life itself that inevitably passes. ${ }^{18}$ This means that, by changing the perspective somewhat - from 'literature to life' our aim here will be to argue that behind the rhetorical literary topos of the time that destroys all the Byzantine princess' intrinsic need for, and attempt at finding, at any costs, an emotive consolation lay. ${ }^{19}$

$* * *$

To begin with, the opening, poetic words from the Alexiad are all too important to be left without quoting it here in full:

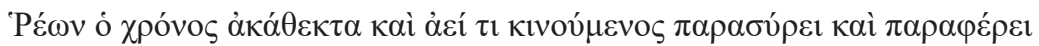

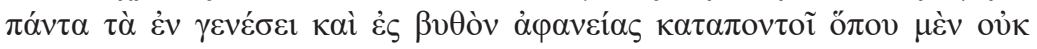

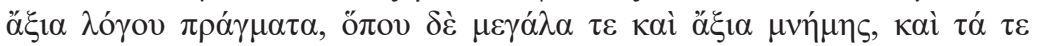

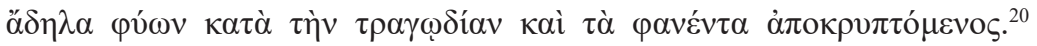

15 In his paper on prooimia in Byzantine historians of the Comnenian era, I. Grigoriadis (1998, esp. 335-337), while agreeing that Anna uses 'clichés', admits, nevertheless, that she shows concern for 'creativity and originality' (he adduces anoher metaphor for time in Alex. praef. 2).

16 Neville 2013; Neville 2019; Neville, Vilimonović 2019: 70.

17 On this see a thoughtful study by R. Macrides (1996).

18 Cf. here Le Poidevin 2017: 219.

19 See here the remarks by N.F. Partner (1986: 91).

20 A famous reference to Sophocles' Ajax, 646-647, that reads: 'A $\pi \alpha v \theta$ ' ó $\mu \alpha \kappa \rho o ̀ \varsigma$

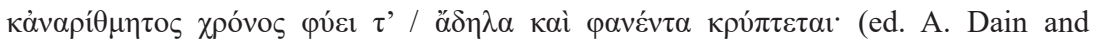
P. Mazon). 


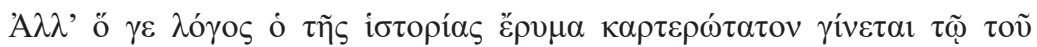

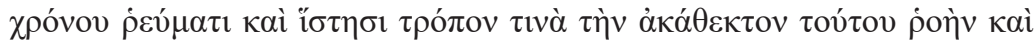

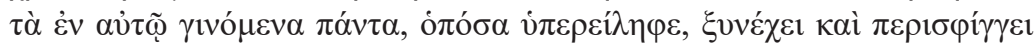

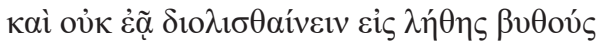

\section{In the Penguin translation by Sewter it runs:}

The stream of Time, irresistible, ever moving, carries off and bears away all things that come to birth and plunges them into utter darkness, both deeds of no account and deeds which are mighty and worthy of commemoration; as the playwright says, it 'brings to light that which was unseen and shrouds from us that which was manifest'. Nevertheless, the science of History is a great bulwark against this stream of Time; in a way it checks this irresistible flood, it holds in a tight grasp whatever it can seize floating on the Surface and will not allow it to slip away into the depths of Oblivion. ${ }^{21}$

It is a pity that in his notae historicae et philologicae to Anna's opus vitae the learned French scholar and polymath Charles Du Fresne Du Cange (1610-1688), known and appreciated for his epoch-making Glossarium ad scriptores mediae \& infimae Graecitatis (1688), ${ }^{22}$ has devoted no word of comment upon this part of Anna's opening introduction to the Alexiad. ${ }^{23}$ But other experts in Byzantine historiography did, however, and it is interesting to observe in what direction their discussion

21 Sewter 1969. In the 2009 Penguin edition the translation was revised by P. Frankopan. It runs: 'Time, which flies irrestibly and perpetually, sweeps up and carries away with it everything that has seen the light of day and plunges it into utter darkness, whether deeds of no signidicance or those that are mighty and worthy of commemoration; as the playwright says, it brings to light that which had been obscure and shrouds from us what had been visible. Nevertheless, the science of History is a great bulwark against this stream of Time; in a way it checks this irrestible flood, it holds in a tight grasp whatever it can seize floating on the Surface and will not allow it to slip away into the dephts of oblivion'; cf. Frankopan 2019: 5.

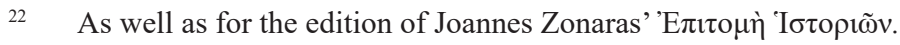

23 Du Cange's commentary has been reprinted in L. Schopen's edition that was revised by A. Reifferscheid: Annae Comnenae Alexiadis libri XV, Vol. II. Bonnae 1878 (in the series 'Corpus Fontium Historiae Byzantinae'). Du Cange's commentary itself (pp. 415-703) bears two titles (pp. 415 and 419, respectively): Caroli Ducangii in Annae Comnenae Alexiadem notae historicae et philologicae / Caroli Du Fresne Ambiani 
went. It appears that the passage in question was interpreted most usually in the terms of rhetorical device. ${ }^{24}$ Indeed, such way of approaching the text is understandable well, for what we have here looks like as an allusion to the topic discussed elsewhere, in many other historical works, from both the distant and closer past, Greek and Roman alike.

Taking it logically, reflections on the lapse of time and 'the past' were always deeply and inseparably connected with the craft of historical writing, ${ }^{25}$ although such topic was not treated in the same way by all those who pursued the past: some mentioned it only, in passing; ${ }^{26}$ others devoted more space to it. ${ }^{27}$ However, as the theme of time that constitutes a deadly danger to men's memorable exploits if nobody takes care to record them was crucial, the frequency of its appearance in historical works made them having been changed into topos ( $\tau$ ó $\pi \circ \varsigma),{ }^{28}$ that is, a motif repeated regularly enough to have become a characteristic feature of the whole literary genre.

Domini Du Cange Quaestoris Franciae in Annae Comnenae Caesarissae Alexiadem notae historicae et philologicae.

24 Cf. Jeffreys 1979: 199; see the two recent inspiring books: Buckley 2014; Neville 2016: 32-33.

25 As Aristotle wrote in his On Memory and Reminiscence; see generally Le Goff 2007: 41; cf. also Olsen 2018: 85.

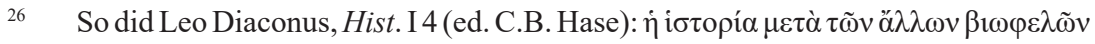

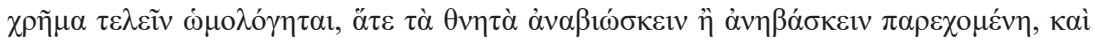

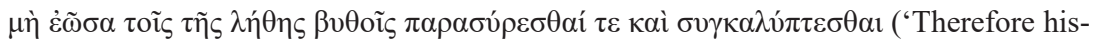
tory is agreed to be as profitable as the other useful things in life, inasmuch as it brings mortal affairs back to life or gives them youthful vigor, and does not allow them to be swept away and concealed in the depths of oblivion'; transl. M.-A. Talbot, D.F. Sullivan); see also Michael Attaleiates, Hist. 2, proem. 2, writing in the second half of the $11^{\text {th }}$ century. In A. Kaldellis and D. Krallis' translation it goes: 'My purpose is to prevent noteworthy matters from slipping into the dephts of oblivion (lethes bythois) through the passage of time (tes tou chronou pararhoes), and to grant them immortal remembrance (ten mnemen athanaton)'. A splendid, and stylistically admirable manifestation of the same type of reasoning is the exquisite closure of Skylitzes' preface (Synop. hist. praef. 1, 50): 'Reading provokes recollection; recollection nourishes and expands memory [...] negligence and laziness provoke forgetfulness which darkens and confuses the memory of that happened in the past' (trans. J. Wortley).

27 Cf. Maisano 1985; Cresci 2004.

28 As T. Pratsch (2005, esp. 35-36) rightly recalls in a highly interesting study that the topos of 'Mittel gegen Vergessen (oblivionis remedium)' was also a feature of Byzantine hagiographical texts. 
When one deals with topoi (in the Roman grammar terminology loci communes, ${ }^{29}$ i.e., 'commonplaces'), it means by the same, of course, that one enters the realm of rhetoric and rhetorical aspect of a given written work. There is, in turn, little wonder that this leads us as back as

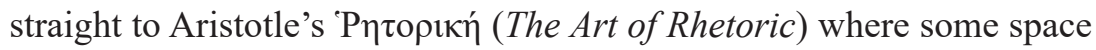
is devoted to explain how a topos works. ${ }^{30}$ Here we can't stop for a long discussion on what $\tau$ ó $\pi$ o $\zeta$ is but suffice it to say that it was apparently understood as a method of developing an argument, therefore one of means of rhetorical persuasion. ${ }^{31}$ In the case of historiography it also became a distinctive trait of a work describing what happened in the past ages. What is here characteristic of Greek historiography (ancient and medieval), however, is not a sophisticated discussion about the nature of time and the past, ${ }^{32}$ but the author's awareness of the significance of the work itself, which, thanks to the recording of great deeds and achievements, ${ }^{33}$

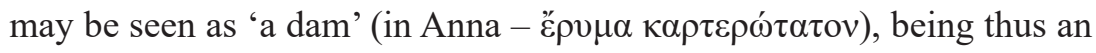
obstacle that is able valiantly to resist the destructive working (i.e., the passage) of time.

Perceiving literary work in the terms whose subject-matter past deeds, mythical and historical alike are, ${ }^{34}$ one must inevitably begin with Homer's masterly epic, the Iliad. Among many things, the poem reveals a great importance the archaic Greek elites gave the songs recited by bards and rhapsodes - both for praising heroic $\kappa \lambda \dot{\varepsilon} \alpha \dot{\alpha} v \delta \rho \tilde{\omega} v,{ }^{35}$ as for the immortalizing of members of warrior-circles who basically constituted its audience. ${ }^{36}$ Later on, one can see the same line of thought in

\footnotetext{
29 Cicero, De inv. II 14; cf. Small 1997: 80-83.

30 Anderson Jr. 2000: 117-120.

31 Although, as modern experts point, it must be recalled that nowhere in the Rhetoric does Aristotle give a clear-cut definition what topos is (but cf. Rhet. 1358a 10) and the same is true as regards his Topica; see Grimaldi 1972: 115-130.

32 See note 14 , above.

33 Cf. Fornara 1988: 1.

34 The distinction is analyzed by P. Vidal-Naquet (1996).

35 See Hornblower 1994: 7 (quoting Hom Il. IX 189, 194; cf. Hom. Od. VIII 73), with Nicolai 20017: 15.

36 See Momigliano 1966: 9. Naturally, for a historian this was also an occasion to present himself (either ostentatiously, or by the way) as, for example, Herodian (I 1) put it eloquently. He states that if the writers who tried ( $\sigma \pi 0 v \delta \alpha \sigma \alpha \dot{v} \tau \omega v)$ to write history

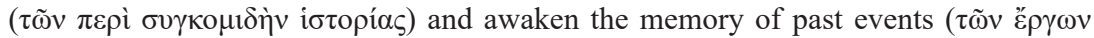


the famous pater historiae, Herodotus, who - his reserve from mythical poetry notwithstanding - adopted it to historiography. Herodotus did not devote too many passages to time as such, yet his concept of history was

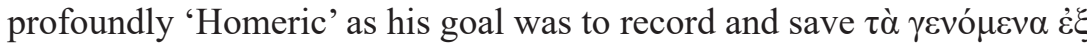

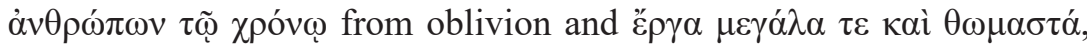
as well. ${ }^{37}$ Clearly, he understood his own written work as an $\dot{\alpha} \pi \delta$ ó $\delta \xi \iota \varsigma$, a display, ${ }^{38}$ so a true monument (Épyov). In this written monument he recorded (and immortalized) how the Greeks fought the Persians which meant, by the same, saving the story of this conflict from forgetfulness and obscurity, in a word - from preventing it to fall into the waves of the

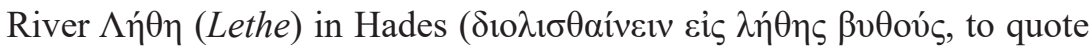
Anna's apt and suggestive metaphor from her Prologue).

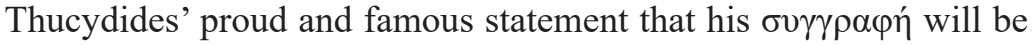

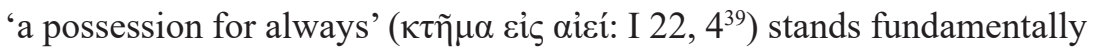

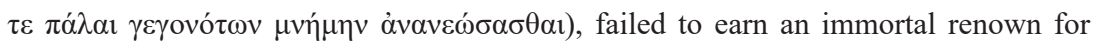

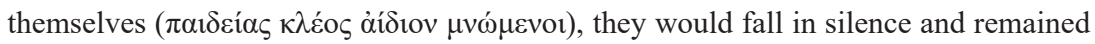

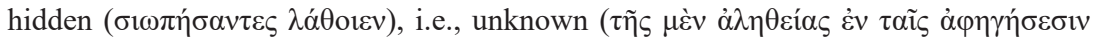

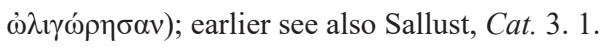

37 Cf. Immerwahr 1960; also Hartog 2002. On history as 'commemorative genre' see Grethlein 2014: 246. Herodotus is recalled by G. Agnello (2010: 299) in his commentary on this prologue.

38 This was consciously imitated as late as in the $15^{\text {th }}$ century AD by the 'last' great

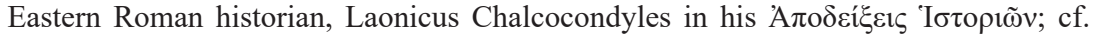
Kaldellis 2014: $\mathrm{x}$.

39 Cf. Marincola 1997; cf. Hornblower 1994. What Thucydides stresses out is that an everlasting actuality of his work will be guaranteed by its utility which makes it a lesson for future politicians and statesmen. But this conviction is logically based on an obvious assumption that the work will present a lot of data from the past. These two features of a history and historical work, too, were defined famously later by Cicero $(D e$ leg. I 5) as vita memoriae, magistra vitae; cf. Grafton 2010: 441. In consequence, the argument of utility of studying both history as a historical account must be understood in terms of the author's efforts to save the past from obscurity: to be sure the argument runs along the lines that access to knowledge about past events through books and studies is beneficial for would-be readers as it offers them plenty of moral lessons, yet this in itself shows the importance of books in recalling and 'stopping' this past. This is evident in Polybius' argumentation as he frequently refers to the utility of his work. Additionally, the same philosophy of a work's moral benefit lies behind Xenophon's Cyropaedia, where he, stressing out how Cyrus' solutions and institutions have a continuation in the author's present (the famous 'eti kai nyn'-formula), takes it for granted that his tale will be advantegous for learning about the Persian monarchy. The idea of 
not far from the Homeric and Herodotean understanding what a poem and historical work, both commemorating great feats, should be - despite all the differences between him and his predecessors that are carefully stressed. ${ }^{40}$ Other clear evidence for taking literature as a monument that withstands the destructive force of time may be Horace's poetry as he himself understood it. His boastful and aphoristical exegi monumentum-avowal from carmen III 30, 1 is fine rhetoric, obviously true, but it remains something much more than mere rhetorical embellishment. ${ }^{41}$ Amongst others Roman writers, we also may mention Vitruvius to whom it was also clear that a knowledge of achievements of past generations is a result of the decision to preserve it in material form - written scrolls. ${ }^{42}$

Just these few examples from Graeco-Roman antiquity, select as they are ${ }^{43}$ though, allow us to agree with Gabrielle M. Spiegel who claimed that 'To the Greeks and Romans, history is an operation against time, an attempt to save human deeds from the futility of oblivion' ${ }^{44}$

utility (next to the intention to continue the work of his predecessor) is also present, for example, in Theophanes the Confessor (Chron. praef. 4; ed. C. de Boor). From Genesius' preface to his On the Reigns we learn that recalling past events is always

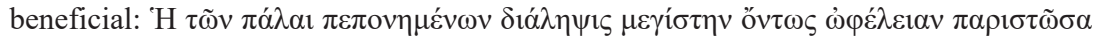

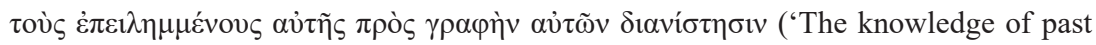
events confers great benefit by itself and can also inspire those who receive that benefit to record those events'; transl. A. Kaldellis).

$40 \quad$ From this perspective, Thucydides' suggestive reconstruction of the earliest Greek history (prehistory, in fact), the famous archaiologia-excurse (Thuc. I 1-21), must be seen as a brave attempt at elucidating and understanding what may be called literally, in the context of the present paper, 'a darkness'; cf. S. Hornblower 2012: 691. There is no need to stress out that the desire to give posterity a record of the glorious deeds of Alexander the Great lay at the roots of so many works on him, with Arrian's Anabasis ahead (Anab. I 12, 5).

${ }_{41} \quad$ See Nisbet, Rudd 2004: ad loc.

$42 \quad$ De archit. 7. praef. 1-2.

$43 \quad$ For other references in philosophical literature see Levi 2018.

44 Spiegel 1997: 86. This observation may be supplemented with a remark by I. Nilsson (2006: 58), who in a poetic manner wrote that the aim of Byzantine historians was 'to breathe life into the dead'. A fine illustration here would be Procopius who in his prologue to De aedificiis (I proem. 1.2) observes on history writing that $\pi \alpha \rho \alpha \pi \varepsilon \dot{\mu} \mu \pi \mathrm{ov \sigma \alpha ́}$

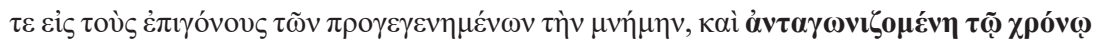

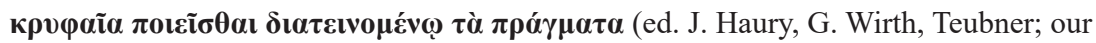
emphasis - B.B. \& M.M.). On Western practices see McKitterick 2000; Carruthers 2008 . 
But the theme survived and was continued down by later writers. Given that medieval Greek historians look back on their ancient predecessors, ${ }^{45}$ it is hardly surprising that things were not different in Byzantine historiography as well, ${ }^{46}$ where similar sentiments also came to the fore. Of course, this is true not just about historiography. By way of illustration, one can recall, for example, one of Anna's eminent predecessors, Emperor Constantine Porphyrogenitus, who in his two prefaces to the De cerimoniis aulae Byzantinae betrays the consciousness of a crucial role of written word in collecting, storaging and reconstructing the imperial rituals and extended court etiquette in Constantinople. ${ }^{47}$ Again, this laborious task is done against the time that is constantly lapsing.

45 See H. Hunger 1969-1970; cf. Cameron 2006: 153.

46 Cf. Lieberich 1913: 223-227.

47 As the learned emperor observes in the praefatio to the Book One (ed. J. Reiske

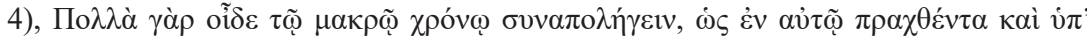

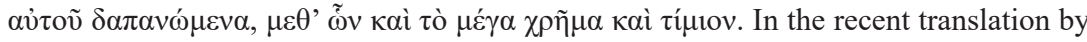
A. Moffatt and M. Tall, it runs: 'Over a long time many things can disappear which, while achieved in that time, are also consumed by it' (our emphasis - B.B. \& M.M.). The same argumentation is seen in his Preface to the Book Two (Reiske 516): O $\pi \varepsilon \rho i$

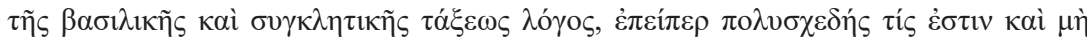

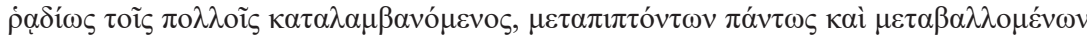

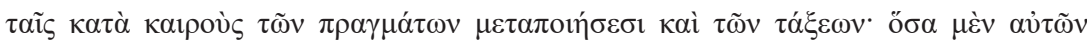

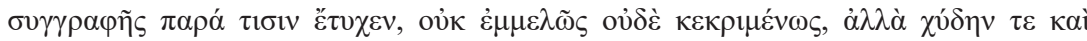

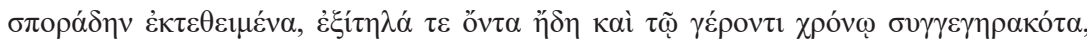

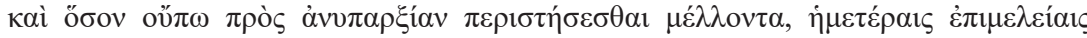

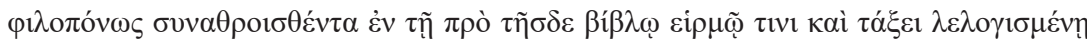

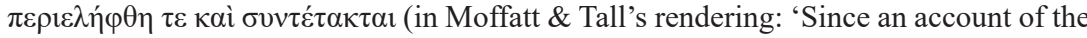
imperial and senatorial orders is a complex matter and for many not easily understood, especially because the arrangements and orders undergo change and are altered with variations to suit the times, such of them as happened to have someone record them have not been set down in either an orderly or discerning way but in an unsystematic and scattered fashion. These were already fading, grown old with the passage of time, and were almost on the threshold of oblivion when they were diligently collected through our efforts and included and arranged in the preceding book in a certain sequence and considered order') [authors' own emphasis - B.B. \& M.M.]. In a recent study on the emperor Constantine VII's idea of preparing extracts (eklogai; Latin: excerpta) from various works, today known as Excerpta Constantiniana, András Németh inserts a translation of the preserved proem to those 53 thematically arranged and titled collections of excerpts (hypotheseis), of which only a few are preserved until now. In the preface we are told that among the learned emperor and his co-authors' intentions 
Additionally, in his commentary Professor Agnello recalls two passages from two Greek medieval novels of the $12^{\text {th }}$ century where a belief may be found as to how destructive power of time and forgetfulness is. ${ }^{48}$

The above extremely selective and short glance at ancient and medieval reflections on the passing of time allow us, nevertheless, to infer that they were frequent enough to become a recurring motif whose works had, if used often, a literary effect. But an analysis of this motif as a rhetorical topos only has, we dare to suggest, its limitations and it is very interesting to observe that this type of approach carries a lot of interpretative limits. The most important, in our opinion, are two. Firstly, the serious limitation is that the aforementioned topos of time lapse proves an observation that is hardly revealing and - to be honest - absolutely banal and trivial, sometimes even irritating. ${ }^{49}$ Such an impression can be obtained after reading, e.g., earlier reflections from the Greek Anthology, say, Palladas' epigrams (X 79; X 84). An educated reader feels that they are dealing with a 'general truth', the so-called 'folk wisdom' (in the pejorative sense of the word) that by its nature contain no original reflections and automatically excludes any inventiveness. This being so, an impression is, it would be pointless to expect and to look for a depth of thought, brilliance and freshness, not to mention of any originality.

But there remains a second consideration, which is much more important to us in this respect: namely, that when dealing with rhetorical

utility and consideration for renown stand out. Nevertheless, the Byzantine collector is aware of 'the passage of so many years' and 'the number of events' which resulted in neglecting the knowledge of the past and history. So, it is plain that his aim was - indirectly - to save those past achievements from vanishing; see Németh 2018: 61.

48 Agnello 2010: 199. The first comes from Eustathius (Eumathius) Macrembolites' Hysmine and Hysminias (XI 20, 20): 'O Poseidon, who took Hysmine as a scapegoat in the storm, $\mathrm{O}$ great Apollo, who bestowed freedom on us, $\mathrm{O}$ bow of Artemis and spring which adjudged her virginity, do not let an abyss of oblivion overwhelm our adventures, nor the passage of time nor decay nor Hades' bowl that pours out forgetfulness'; the second may be found in Theodore Prodromus' Rhodanthe and Dosicles (II 241-245): 'Time would not have the power/to wipe away so quickly from our midst/Lysippos' many commands/and his many efforts in so many battles/, and submerge them in the abyss and obliteration of oblivion' (both translations by E. Jeffreys); for a highly valuable introduction see Beaton 1996.

49 On this see Magdalino 1983: 328-239 (the reference to this study we owe to: Ljubarskij 1998: 6). 
aspect of a work you are willing not to take the author's emotions seriously. In effect, we admit that we cannot know about them, so we are unable to speak about them for certain. All (or: almost all) of what is written, i.e. turned into a text becomes a topos (topoi), adopted by the writer, in accordance with the principles required by literary convention. Thus it is the literary practice of reading of, alluding to, paraphrasing, or quoting we can only talk about. ${ }^{50}$ To seek for author's honest and genuine feelings is, the argument runs, inappropriate in many cases because we simply have no way of knowing how much these emotions were exaggerated. Since a writer, working according to literary schemas, is led by a long literary tradition and conventions, there should be no question of 'honesty' in his argumentation - a literary strategy/strategies is merely what matters. Such or similar beliefs prevail now as almost common, and this underlies the enduring controversy about the nature of ancient (and also medieval) historiography, ${ }^{51}$ treated, after Cicero, as opus oratorium maxime, whose main aim was to present deeds interestingly. ${ }^{52}$ Such a conclusion is additionally justified in light of the fact that since Antiquity emotions ( $\tau \dot{\alpha} \pi \alpha \dot{\alpha} \theta \eta^{53}$ ) were a matter of analysis in the treatises of rhetoric. ${ }^{54}$

Anna's case would correspond to the above argumentation. This is more obvious and more she frequently reminds her learned addressee of how many books of the ancient Greeks she read and what an exceptional and careful education she received, ${ }^{55}$ with a particular accent she puts on her knowledge of philosophy. ${ }^{56}$ Therefore, given all that a serious objection arises in this case, too: how do you know for sure how much rhetorical affectation and stance there is with Anna, and how authentic her

50 Which essentially fits the definition of intertextuality. On Byzantine readership in general see Wilson 1975; Wilson 1996; also Shawcross 2018.

51 See Murphy 1981. On the function of topics in the medieval literature see Curtius 1997. At p. 495 he quotes the poem Johannis by Corippus (about 550 AD): Omnia nota facit longaevo littera mundo / Dum memorat veterum proelia cuncta ducum, as Littera priscum commemorat opus.

52 Cf. Woodman 1988. On this more generally: Fox, Livingstone 2007.

53 Arist. Rhet. 1378 a.

54 Cf. Kennedy 1963.

55 See Hunger 1978: 408; cf. Croke 2010: 42-43.

$56 \quad$ Alex. XV 7, 9; cf. Cooper 2013: 270; also S. Gouguenheim (2017: 70-71) quotes Alex. XV 7, 9. 
emotions are? Is her hysteria (let's be frank) and the somewhat explosive nature of this passionate woman authentic and sincere,${ }^{57}$ or are they 'artificial' to a great degree, a product of the author's sophisticated creativity, carefully (rhetorically) arranged and openly studied $?^{58}$

The above question cannot be, naturally, addressed decisively, in simple yes/no terms. As we observed above, it is not our goal to deny or diminish the value of the literary approach to a written text, preceive the evidence for an author's rhetorical strategies or techniques. After all, anyone agrees, anything in a written text may be seen as result of an author's pursuit of literary 'strategies'. Accordingly, already in the Art of Rhetoric $(1414 \mathrm{~b} 20$ - 1415a12) Aristotle included an introduction to the essential parts of a speech (as was the prologue in tragedy). Seen in this light, Anna's prologue of course remains a part of her 'rhetoric' and persuasive techniques, too. ${ }^{59}$

This being so, we would like, nevertheless, to return to another, indeed crucial observation 'the prince of philosophers' has made. It simply concerns sources of memory. As as far as that is concerned, in the short

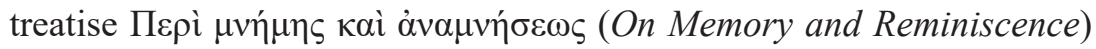
Aristotle explicitly points out that source of remembrance may be only what happened in the past - in fact we are dealing either with our own, or someone else's experiences. ${ }^{60}$ Thus, to put it simply, material for rhetoric, as well as the substance of literature is life itself which is why literature and iconography have are basically of a mimetic nature: they just imitate life. So, what about Anna in this respect?

57 For signs of hysteria and megalomania in the princess see Buckler 1929: 35-40.

58 Here the three passages from the Prologue (IV 1-4. 3) Professor Neville quotes in her book (2016: 39-41), may serve as a good example; see generally Hinterberger 2010: 123-124; also Quandahl, Jarratt 2008. On Anna's emotions also recently Constantinou 2019: 291-296.

59 The tradition to see prologue as an integral part of a speech, so the subject of rhetoric, was vivid among Byzantine scholars, to mention the learned Michael Psellus and his didactic poem On Rhetoric, vv. 81-139; cf. Walker 2001; see Conley 2005: 678-679; also Papaioannou 2017.

60 See Sorabji 1972: 35-46; cf. D. Bloch's remarks (2007: 72-73). For a recent reassessment see Whitehead 2009 (esp. 24-27). 
It is maintained that the learned princess wrote her tale in the 40s of the twelfth century, in the first years of the reign of her nephew, Emperor Manuel (1143-1180), ${ }^{61}$ whom she, anyway, despised (Alex. XIV 3, 9). She was then about $60 .{ }^{62}$ Her father, the hero of her epic tale, was long since dead (1118). Her mother, the Empress Irene Ducaena, ${ }^{63}$ and her beloved husband Nicephorus Bryennius in $1137,{ }^{64}$ as well as her younger brother, Emperor Joannes, ${ }^{65}$ to whom she lost the opportunity and rights to the throne ${ }^{66}$ - all left this world as well. Over 20 years she remained 'in exile' out of the imperial court, in seclusion in a monastery (naturally, it was not in isolation or prison - Alex. XVII 7, 6) in Constantinople. ${ }^{67}$ The exact date of Anna's death is unknown but it is believed that in 1143 she still had about 10 years to live - long enough to refresh memories, ${ }^{68}$ fueled by vibrant emotions; and - above all - enough to produce the literary masterpiece, therefore to immortalize her father and herself against all odds.

One can imagine her, for a while, writing in a room of the monastery tès Kecharitomenēs. ${ }^{69}$ It is very possible that during this longtime, forced stay she must have had the same feelings as Horace did many hundreds of

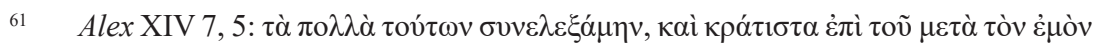

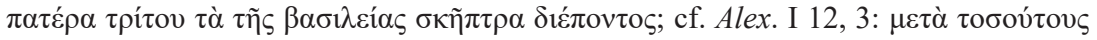

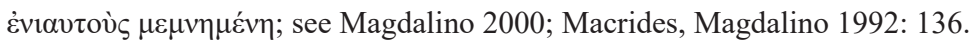

62 Cf. R. Browning's seminal study (1962); see Nilsson 2014: 122.

63 Probably in 1123.

64 A detailed, thoughtful treatment of his life and work remains now the study of L. Neville (2012); cf. Franchi 2019: 129.

65 Emperor Joannes died in 1143; see Magdalino 2008.

66 It was Zonaras (Epit. hist. XVIII 28-29) who reported her sharp dispute with Joannes and a coup d'état to murder him in order to become an empress; see Browning 1992: 165; Garland 1998: 195-199; Neville 2016: 4-7.

${ }_{67}$ Macrides, Magdalino 1992; on realities of living in monasteries see Patlagean 1987: 561-579.

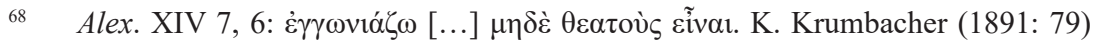
thinks that the work was finished in 1148.

69 One of the merits of Professor Browning's paper (1962) is mining to light and - nomen omen - saving information of a preserved epitaphios logos that was written in loving memory of Anna from obliteration, so by the same giving a reminder about this somewhat forgotten author, bishop Georgius Tornices. Evidently he was a friend of Anna and her mother and visited both noblewomen in the monastery; cf. Rosenqvist 2007: 128-129. 
years earlier, meditating on innumerabilis / annorum series et fuga temporum. ${ }^{70}$ Such were the thoughts of the woman whose two closest people to her - mother and husband - passed away which led her to take on the laborious challenge that may be called, to paraphrase Marcel Proust, récupération du temps perdu. What she took on to do was to stop the passing of time by the intensivity of recollecting events from her youth and adult life that would rescue the figure of the beloved father from oblivion.

Taking all the differences into account, the circumstances of composing the Alexiad recall, to some extent, those presented to us by Professor Eco in Il nome della rosa. In the place of Anna take Adso of Melk, the narrator and protagonist of the memorable novel. And as in the case of the Alexiad, one gets, first and foremost, memories of amazing and terrifying life experiences of the young narrator. But his senile complaint about a transitory nature of everything ('Est ubi gloria nunc Babylonia? Dove sono le nevi di un tempo? La terra danza la danza di Macabré, mi sembra a tratti che il Danubio sia percorso da battelli carichi di folli che vanno verso un luogo oscuro' ${ }^{71}$ ) is clear enough, given that he, a man of old age, writes down many years later which simply means the act of recollecting, made in order, not the least, to pay tribute to his deceased master, Willliam of Baskerville.

Thus, how to understand Anna's introductory, general reflection on time (in a way, almost personified ${ }^{72}$ ), memory and oblivion? This is a highly interesting issue, especially in the light of modern scholarly controversies how to understand Byzantine literature in general, and how to read Byzantine historiography, in particular. ${ }^{73}$ As we noted previously, our point of departure was that the rhetorical approach, which is otherwise justified and understandable, does not tell the whole truth. Instead,

\footnotetext{
70 Hor. Carm. III 30, 4-5.

71 It would be tempting to add the mention of snow recalls the Horatian longing for yesterday that has passed: diffugere nives.

72 As in the inscription from the Anthologia Graeca (VII 245), in honor of the fallen at Chaeronea in 338 BC (= Tod 1948: 223-224, no. 176):

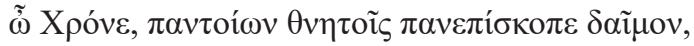

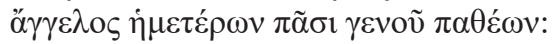

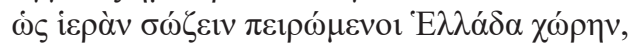

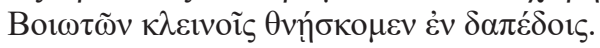


what we argue here is that in this particular case 'the priority of life'-rule should be taken into consideration as the main factor. This means that life is prior to a text, so it may then be 'textualized', i.e. changed into a written form. Taking this as a starting point, such an interpretation allows us to claim that Anna's lamentation was really tragic and authentic. Accordingly, what we read in the beginning of the Prologue is not only an elegy and mourning of her loved ones who left her forever, but - by the same - mourning of time that has gone irreversibly forever, and ipso facto - of life that turned out this and not another way, and was, at the moment of writing, irrevocably ending. So, whining over a drastic change in author's life, Anna's personal 'threnody' becomes something more; it constitutes a more universal lament over 'transitoriness of time'

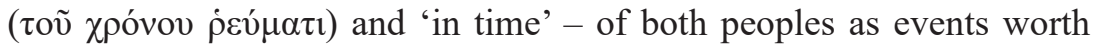

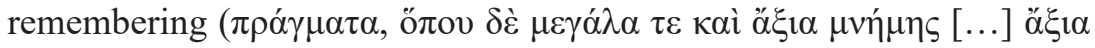
$\lambda$ ó $o v)$. Thus composing its work with hindsight, Anna's fear concerned either the disappearance of people or falling past events into mere noth-

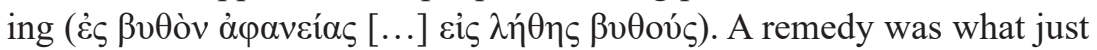

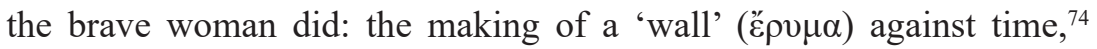

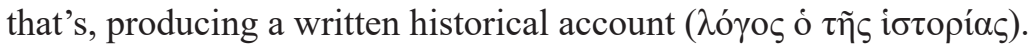

To sum up: in the case of the Byzantine princess it was her personal experience of life and her life itself (which, let us add, for the ancient and medieval Greeks was $\delta \rho \tilde{\alpha} \mu \alpha$, something that goes on and most often is tragic - in the modern sense of the word ${ }^{75}$ ) that became, after many years, the subject of pensive meditation. This reflection resulted in her acute, 'Heraclitean' and Stoic awareness of the passing of everything around. ${ }^{76}$ Our point is thus: ancient literary patterns (rhetorical commonplaces) helped Anna to address this issue in a more sophisticated, more sublime, and more beautiful way but, again, it was her life itself that provided inspiration here.

\section{$* * *$}

Several years ago Professor Norman Davies counted Byzantium amongst those past kingdoms that once flourished, which played a great political

\footnotetext{
$74 \quad$ Cf. Papalexandrou 2010: 118-119.

$75 \quad$ See Buckley 2014: 38.

76 On 'time awareness' in classical Greek literature see generally de Jong, Nünlist 2007: 506 .
} 
role, only to fade and to disappear finally after 1453 - a process whose sustained consequence today is relatively small knowledge of the Eastern Roman Empire and its culture. ${ }^{77}$

Fortunately, this state is slowly being changed and for any ordinary reader, oriented in the studies of Byzantine culture (with its literature) two things become much clearer. First, what a vast and priceless treasure was left by the literary elite of the Eastern Roman Empire during the thousand years of its existence; second, how great its impact on Europe and Orient was. ${ }^{78}$ There is currently a period of 'a renaissance' of Byzantine Studies, undoubtedly; Byzantine literature is becoming 'visible', really. ${ }^{79}$ Amid this huge literary collection the $A \lambda \varepsilon \xi$ ía ${ }_{\varsigma}$ is certainly one of the most splendid gems, a cameo. For two reasons, precisely. Firstly, it remains an invaluable historical source, though far from being objective or unbiased or impartial - just like any other. ${ }^{80}$ Secondly, an enduring value (and allure) of the Alexiad lies just in the fact that it reveals, almost on every page, the author's strong emotional engagement in the events that are recalled. The narrative, although written from a certain time perspective, it is everything but a dry report. Far from it. Composed by the talented and exalted, indeed an exceptionally ambitious, impetuous and passionate woman, ${ }^{81}$ her narrative still lives on. How many historical narratives from the distant past can you say the same about?

The efforts of investigation of the past (Herodotean i $\sigma \tau$ opí) were aimed at reaching what in ancient Greek was termed $\dot{\alpha} \lambda \dot{\eta} \theta \varepsilon ı \alpha$. Usually we take it to mean 'truth' now but the term, remarkably, refers literally to 'unconcealment', 'recovering from oblivion', or 'unforgetfulness'. ${ }^{82}$

77 Davies 2011; cf. the remarks of A. Cameron in her excellent essay: 'Introduction. Byzantines and Others' (2019: 6-7).

78 See Cameron 2018: 120.

79 In 1990 M. Mullett wrote of 'invisibility of Byzanine literature' (1990: 261).

80 Scott 2010: 260; cf. Haussig 1969: 332; Kaldellis 2017: 287.

81 See on this also Stanković 2011: 64. L. Neville (2016: 5-6) quotes Constantine Cavafy's famous poem on the emotional character of Anna's Prologue.

$82 \quad$ Frisk 1960: 71; Chantraine 1984: 618 (s.v. $\lambda \alpha v \theta \alpha ́ v \omega)$; Beekes 2010: 66; also Marincola 2007. It would be of some interest to mention here that almost the same argument was reminded by the eminent Polish historian Jan Długosz (Ioannes Dlugossius, or Longinus), written in the second half of the $15^{\text {th }}$ century. In the Preface to his great Annales seu Cronicae incliti Regni Poloniae he states that if exploits that were good 'will be given to books', they never will fade and perish, even if memory is transitory 
As logic requires, seeking truth always was and still is (it is to be hoped) connected inseparably with memory and remembering. This was Anna's essential goal, indeed as writing history is always an act of recollection. ${ }^{83}$ Additionally, to recall the reign and glorious deeds of her dearest father, meant, to the same degree, the best way for having been kept herself in the memory of future generations.

In doing so she was no exception. This latter goal, to survive to be remembered by posterity, seems to be almost universal among writers (there were exceptions, of course), irrespective of eras and cultures, irrespective of whether they talk openly about it, make veiled allusions, or try to omit it all together. Again, such an authorial effort points inevitably to an author's awareness of the status of one's own work, reminding the famous Horatian non omnis moriar-memento, afresh.

As a significant example of such a (well-nigh) universal nature of the art and process of writing it be would adequate here to recall a literary piece of such a different format as Vladimir Nabokov's famous Lolita certainly is. At the very end of the novel the narrator, addressing the absent heroine, says her that she should not regret what happened: 'And do not pity C. Q. One had to choose between him and H. H., and one wanted H. H. to exist at least a couple of months longer'. Then, he goes on explain her (and us, the readers, who have reached the closure of the novel) why: 'so as to have him make you live in the minds of later generations'. This is a truly touching, if somewhat unexpected ending, for, in other words - as the narrator ultimately turns to his beloved - 'this

and lasts for one human generation, at best. Thus he further complains that so many noble deeds remain unknown in fact as there are no talented writers to record these uncommon feats. Regarding this, the Polish chronicler observes in another place of his Preface that, if any famous achievement will be not followed by a description worthy of it, soon time and obliviousness will cover it. Many splendid exploits of the kings and emperors lie burried and are forever forgotten, the learned canon continues to moan with some rhetorical outburst, and the reason behind such a deplorable state is that human actions are casual and passing while written monuments are not; conversely - their durability allows them to compete with immortality

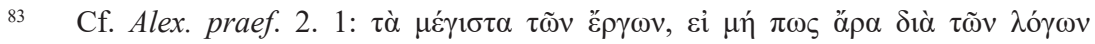

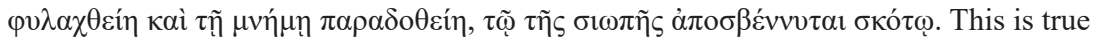
in the case of Psellus and his famous Chronography as his narrative of the reign of a few emperors is, at the same time, memorials of eyewitness. On writing as a metaphor for memory see Danziger 2008: 32 . 
is the only immortality' he can share with her, evidently on the grounds that lasting memory can solely be provided in a written story.

If only it were possible and the proud Roman princess of Constantinople - from another, distant time, and from a different culture - would read Nabokov's words, one would be allowed to believe that she would agree with this belief. So finally, as regards the first paragraph of the Prologue to the Alexiad, it may be interpreted as a literary topos; eventually one can see it as an example of 'inherited convention', ${ }^{84}$ indeed. But in either case, behind Anna's rhetoric bare life stood.

\section{REFERENCES}

\section{Primary sources}

Anna Comnena, Alessiade. Opera storica di una principessa porfirogenita bizantina, a cura di G. Agnello, Salerno 2010.

Anna Comnene, The Alexiad, transl. E.R.A. Sewter, Harmondsworth 1969.

Anna Komnena, Aleksjada, vol. I-II, transl. O. Jurewicz, Wrocław 2005.

Anna Komnene, Alexias, ed. D.R. Reinsch, Berlin 2001.

Constantine Porphyrogennetos, The Book of Ceremonies, transl. A. Moffatt, M. Tall, Leiden - Boston 2012.

Four Byzantine Novels. Theodore Prodromos, Rhodanthe and Dosikles; Eumathios Makrembolites, Hysmine and Hysminias; Constantine Manasses, Aristandros and Kallithea; Niketas Eugenianos, Drosilla and Charikles, transl. E. Jeffreys, Liverpool 2012.

Genesios, On the Reigns of the Emperors, transl., comment. A. Kaldellis, Canberra 1998.

Genesius, B $\alpha \sigma \lambda \lambda \varepsilon i \alpha$, ed. A. Lesemueller-Werner, I. Thurn, Berolini et Novi Eboraci 1978.

John Skylitzes, A Synopsis of History 811 - 1057, transl. J. Wortley, Cambridge 2010.

Michael Attaleiates, The History, transl. A. Kaldellis, D. Krallis, Cambridge, Mass. - London 2012.

${ }^{84}$ The term of Sir C. Mango (1984). R.-J. Lilie (2014: 161) says that 'the prefaces themselves are shaped by tradition'. 
Prefazioni, prologhi, proemi di opere tecnico-scientifiche latine, a cura di C. Santini, N. Scivoletto, Roma 1990.

The History of Leo the Deacon. Byzantine Military Expansion in the Tenth Centu$r y$, transl. M.-A. Talbot, D.F. Sullivan, Washington D.C. 2005.

\section{Secondary sources}

Anderson Jr. R.D., 2000, Glossary of Greek Rhetorical Terms Connected to Methods of Argumentation, Figures and Tropes from Anaximenes to Quintillian, Leuven.

Angold M.A., 2004, 'The Byzantine Empire, 1025-1118', [in:] The New Cambridge Medieval History, vol. IV.2, D. Luscombe, J. Riley-Smith (eds.), Cambridge 2004, pp. 217-253, https://doi.org/10.1017/CHOL9780521414111.010.

Beaton B., 1996, The Medieval Greek Romance, London - New York.

Beekes B., 2010, Etymological Dictionary of Greek, vol. I, Leiden - Boston 2010.

Bloch D., 2007, Aristotle on Memory and Recollection, Leiden - Boston, https:// doi.org/10.1163/ej.9789004160460.i-276.

Brown P., 1993, Augustyn z Hippony, tłum. W. Radwański, Warszawa.

Brown P., 2000 (19671), Augustine of Hippo: A Biography, Berkeley - Los Angeles.

Browning R., 1962, ‘An Unpublished Funeral Oration on Anna Comnena', Proceedings of Cambridge Philological Society 188, pp. 1-12, https://doi. org/10.1017/S0068673500005290.

Browning R., 1992, The Byzantine Empire, Washington, DC.

Buckler G., 1929, Anna Comnene. A Study, Oxford.

Buckley P., 2014, The Alexiad of Anna Komnene. Artistic Strategy in the Making of a Myth, Cambridge, https://doi.org/10.1017/CBO9781139583879.

Cameron A., 2006, The Byzantines, Malden - Oxford.

Cameron A., 2014, Byzantine Matters, Princeton - Oxford, https://doi. org/10.1515/9781400850099.

Cameron A., 2018, 'The Empire of Byzantium', [in:] The Medieval World. Second Edition, P. Linehan, J.L. Nelson, M. Costambeys (eds.), Abingdon - New York, pp. 106-125, https://doi.org/10.4324/9781315102511-7.

Cameron A., 2019, 'Introduction. Byzantines and Others', [in:] Byzantium in Dialogue with the Mediterranean. History and Heritage, D. Slootjes, M. Verhoeven (eds.), Leiden - Boston, pp. 6-23.

Carruthers M., 2008, A Book of Memory. The Study of Memory in Medieval Culture, Cambridge, https://doi.org/10.1017/CBO9781107051126. 


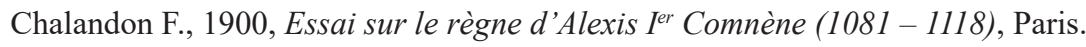

Chantraine P., 1984, Dictionnaire etymologique de la langue grecque. Historire des mots, Paris.

Charanis P., 1952, 'Aims of the Medieval Crusades and How They Were Viewed by Byzantium', Church History 21, pp. 123-134, https://doi.org/10.2307/3161078.

Conley T.M., 2005, 'Byzantine Criticism and the Uses of Literature', [in:] The Cambridge History of Literary Criticism, vol. II, A. Minnis, I. Johnson (eds.), Cambridge 2005, pp. 667-692, https://doi.org/10.1017/CHOL9780521300070.028.

Constantinou S., 2019, 'Gendered Emotions and Affective Genders: A Response', [in:] Emotions and Gender in Byzantine Culture, S. Constantinou, M. Meyer (eds.), Cham, pp. 283-315, https://doi.org/10.1007/978-3-319-96038-8_10.

Cooper G.M., 2013, 'Byzantium between East and West: Competing Hellenism in the Alexiad of Anna Komnene and Her Contemporaries', [in:] East Meets West in the Middle Ages and Early Modern Times. Transcultural Experiences in the Premodern World, A. Classen (ed.). Berlin - Boston 2013, pp. 263-290.

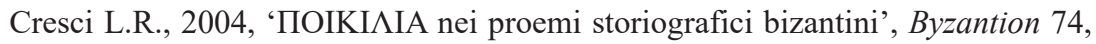
pp. 330-347.

Croke B., 2010, 'Uncovering Byzantium's Historical Audience', [in:] History as Literature in Byzantium, R. Macrides (ed.), Abingdon - New York 2010, pp. 25-53.

Curtius E.R., 1997 (1948¹), Literatura europejska i łacińskie średniowiecze, transl. A. Borowski, Kraków.

Danziger K., 2008, Marking the Mind. A History of Memory, Cambridge, https:// doi.org/10.1017/CBO9780511810626.

Davies N., 2011, Vanished Kingdoms. The History of Half-Forgotten Europe, London.

de Jong I.J.F., Nünlist R., 2007, 'Epilogue’, [in:] Time in Ancient Greek Literature, I.J.F. de Jong, R. Nünlist (eds.), Leiden - Boston, pp. 505-522, https://doi. org/10.1163/ej.9789004165069.i-542.195.

Dölger F., 1966, 'Byzantine Literature', [in:] The Cambridge Medieval History, vol. IV.2: The Byzantine Empire, J. Hussey (ed.), Cambridge, pp. 207-264.

Fornara Ch.W., 1988, The Nature of History in Ancient Greece and Rome, Berkeley - Los Angeles - London.

Fox M., Livingstone N., 2007, 'Rhetoric and Historiography', [in:] A Companion to Greek Rhetoric, I. Worthington (ed.), Malden - Oxford, pp. 542-561, https://doi.org/10.1002/9780470997161.ch35. 
France J., 1983, 'Anna Comnena, the Alexiad, and the First Crusade', Reading Medieval Studies 10, pp. 20-38.

France J., 1994, Victory in the East. A Military History of the First Crusade, Cambridge, https://doi.org/10.1017/CBO9780511562426.

Franchi R., 2019, 'Komnenian Empresses: From Powerful Mothers to Pious Wives', [in:] Piroska and the Pantokrator: Dynastic Memory, Healing and Salvation in Komnenian Constantinople, M. Sághy, R. Ousterhout (eds.), Budapest - New York, pp. 121-142.

Frankopan P., 2001, 'Perception and Projection of Prejudice: Anna Comnena, the Alexiad and the First Crusade', [in:] Gendering the Crusades, S.B. Edington, S. Lambert (eds.), Cardiff, pp. 559-576.

Frankopan P., 2012, The First Crusade. The Call from the East, Cambridge (Mass.), https://doi.org/10.4159/harvard.9780674064997.

Frankopan P., 2017, 'Re-Interpreting of the Role of Family in Comnenian Byzantium. Where Blood Is Not Thicker Than Water', [in:] Byzantium in the Eleventh Century. Being in between, M.D. Lauxtermann, M. Whittow (eds.), Abingdon - New York, pp. 181-196, https://doi.org/10.4324/9781315208541-12.

Frankopan P., 2019, 'Why We Need to Think about the Global Middle Ages', Journal of Medieval Worlds 1, pp. 5-10, https://doi.org/10.1525/jmw.2019.100002.

Frisk H., 1960, Griechisches etymologisches Wörterbuch, vol. I, Heidelberg.

Garland L., 1998, Byzantine Empresses. Women and Power in Byzantium, AD 5271204, London - New York.

Geanakoplos D.J., 1984, Byzantium. Church, Society, and Civilization Seen through Contemporary Eyes, Chicago - London 1984.

Gouguenheim S., 2017, La gloire des Grecs. Sur certains apports culturels de Byzance à l'Europe romane ( $X^{e}$ - début du XIII ${ }^{e}$ siècle), Paris.

Grafton A., 2010, 'Historiography', [in:] The Classical Tradition, A. Grafton, G.W. Most, S. Settis (eds.), Cambridge (Mass.) - London, p. 441.

Grethlein J., 2014, 'The Many Faces of the Past in Archaic and Classical Greece', [in:] Thinking, Recording, and Writing History in the Ancient World, K.A. Raaflaub (ed.), Malden - Oxford 2014, pp. 234-255, https://doi. org/10.1002/9781118412541.ch12.

Grigoriadis I., 1998, 'A Study of the Prooimion of Zonaras' Chronicle in Relation to Other $12^{\text {th }}$-Century Prooimia', Byzantinische Zeitschrift 91, pp. 327-344, https://doi.org/10.1515/byzs.1998.91.2.327.

Grimaldi W.M.A., 1972, Studies in the Philosophy of Aristotle's Rhetoric, Wiesbaden. 
Haldon J., 2000, Byzantium. A History, Stroud.

Harris J., $2014\left(2003^{1}\right)$, Byzantium and the Crusades, London, https://doi. org/10.5040/9781474210508.

Hartog F., 2002, 'The Invention of History: From Homer to Herodotus', [in:] Turning Points in Historiography. A Cross-Cultural Perspective, E. Wang, G.G. Iggers (eds.), Rochester - Woodbridge, pp. 19-30.

Haussig H.W., 1969, Historia kultury bizantyńskiej, transl. T. Zabłudowski, Warszawa.

Herrin J., 2009, Bizancjum. Niezwykte dziedzictwo średniowiecznego imperium, transl. N. Radomski, Poznań.

Hinterberger M., 'Emotions in Byzantium', [in:] A Companion to Byzantium, L. James (ed.). Malden - Oxford - Chichester, pp. 123-134, https://doi. org/10.1002/9781444320015.ch10.

Hornblower S., 1994, 'Introduction', [in:] Greek Historiography, S. Hornblower (ed.), Oxford 1994, pp. 1-72.

Hornblower S., 2012, 'Historiography, Greek', [in:] The Oxford Classical Dictionary. Fourth Edition, S. Hornblower, A. Spawforth, E. Eidinow (eds.), Oxford 2012, p. 691, https://doi.org/10.1093/acref/9780199545568.001.0001.

Horrocks G., 1997, Greek. A History of the Language and Its Speakers, LondonNew York.

Howard-Johnston J., 1996, 'Anna Komnene and the Alexiad', [in:] Alexios I Komnenos. Papers of the Second Belfast Byzantine International Colloquium, 1416 April 1989, M. Mullett, D. Smythe (eds.), Belfast, pp. 260-302.

Howard-Johnston J., 2018, 'Bilingual Reading, the Alexiad and the $\mathrm{Ge}$ sta Roberti Wiscardi', [in:] Reading in the Byzantine Empire and Beyond, T. Shawcross, I. Toth (eds.), Cambridge, pp. 467-498, https://doi. org/10.1017/9781108289993.024.

Hunger H., 1969-1970, 'On the Imitation (MIMH $\Sigma \mathrm{I} \Sigma$ ) of Antiquity in Byzantine Literature', Dumbarton Oaks Papers 1969-1970, pp. 15-38, https://doi. org/10.2307/1291289.

Hunger H., 1978, Die hochsprachliche profane Literatur der Byzantiner, München. Immerwahr H.R., 1960, 'Ergon: History as a Monument in Herodotus and Thucydides', American Journal of Philology 81, pp. 261-290, https://doi. org $110.2307 / 292519$.

Janson T., 1964, Latin Prose Prefaces. Studies in Literary Conventions. Stockholm. Jeffreys E.M., 1979, 'The Attitude of Byzantine Chroniclers towards Ancient History’, Byzantion 49, pp. 199-238. 
Jurewicz O, 1984, Historia literatury bizantyńskiej, Wrocław.

Jurewicz O., 2005, 'Wstęp', [in:] Anna Komnena, Aleksjada, vol. I., transl. O. Jurewicz, Wrocław, pp. V-XXX.

Kaldellis A., 2010, 'The Corpus of Byzantine Historiography. An Interpretive Essay', [in:] A Byzantine World, P. Stephenson (ed.), Abingdon - New York, pp. 211-222.

Kaldellis A., 2014, A New Herodotus. Laonikos Chalkokondyles on the Ottoman Empire, the Fall of Byzantium, and the Emergence of the West, Washington.

Kaldellis A., 2017, Streams of Gold, Rivers of Blood. The Rise and Fall of Byzantium, 955 A.D. to the First Crusade, Oxford.

Kazhdan A., 1991, 'Komnene, Anna', [in:] The Oxford Dictionary of Byzantium, vol. II, A. Kazhdan (ed.), Oxford, p. 1142.

Kazhdan A., 2001, 'Latins and Franks in Byzantium: Perceptions and Reality from the Eleventh to the Twelfth Century', [in:] The Crusades from the Perspective of Byzantium and the Muslim World, A.E. Laiou, R.P. Mottahedeh (eds.), Washington D.C., pp. 83-100.

Kennedy G.A., 1963, The Art of Persuasion in Greece, Princeton.

Krumbacher K., 1891, Geschichte der byzantinischen Literatur von Justinian bis zum Ende des oströmischen Reiches (527-1453), München.

Lauxtermann M.D., 2017, 'Introduction', [in:] Byzantium in the Eleventh Century. Being in between, M.D. Lauxtermann, M. Whittow (eds.), Abingdon - New York, pp. 1-2.

Le Goff J., 2007, Historia i pamięć, transl. A. Gronowska, J. Stryjczyk, Warszawa, https://doi.org/10.31338/uw.9788323526629.

Le Poidevin R., 2017, 'Memory and the Metaphysics of Time', [in:] The Routledge Handbook of Philosophy of Memory, S. Bernecker, K. Michaelian (eds.), Abingdon - New York 2017, pp. 219-227, https://doi. org/10.4324/9781315687315-18.

Levi A., 2018, Il concetto di tempo nella filosofia classica. Dalla Grecia antica all'età imperiale, Roma.

Lieberich H., 1899, Studien zu den Proömien in der griechischen und byzantinischen Geschichtsschreibung I. Die griechischen Geschichtsschreiber, München.

Lieberich H., 1900, Studien zu den Prö̈mien in der griechischen und byzantinischen Geschichtschreibung II. Die byzantinischen Geschichtschreiber und Chronisten, München. 
Lilie R.-J., 2014, 'Reality and Invention: Reflections on Byzantine Historiography', Dumbarton Oaks Papers 68, pp. 157-210.

Ljubarskij J., 1998, 'Quellenforschung and/or Literary Criticism. Narrative Structures in Byzantine Historical Writings', Symbolae Osloenses 73, pp. 5-22, https://doi.org/10.1080/00397679808590934.

Ljubarskij J., 2000, 'Why Is the Alexiad a Masterpiece of Byzantine Literature?', [in:] Anna Komnene and Her Times, T. Gouma-Peterson (ed.), New YorkLondon, pp. 169-185, https://doi.org/10.4324/9780203765234-9.

Ljubarskij J., 2003, 'How Should a Byzantine Text Be Read?', [in:] Rhetoric in Byzantium, E. Jeffreys (ed.), Aldershot - Burlington, pp. 117-125, https://doi. org/10.4324/9781315088686-9.

Macrides R., 1996, 'The Historian in the History', [in:] $\Phi \mathrm{I} \Lambda \mathrm{E} \Lambda \Lambda \mathrm{HN}$. Studies in Honour of Robert Browning, C.N. Constantinides et al. (eds.), Venezia 1996, pp. 205-224.

Macrides R., 2000, 'The Pen and the Sword: Who Wrote the Alexiad?', [in:] Anna Komnene and Her Times, T. Gouma-Peterson (ed.), New York - London, pp. 63-82, https://doi.org/10.4324/9780203765234-4.

Macrides R., Magdalino P., 1992,: 'The Fourth Kingdom and the Rhetoric of Hellenism', [in:] Perception of the Past in Twelfth-Century Europe, P. Magdalino (ed.), London - Rio Grande, pp. 117-156.

Magdalino P., 1983: 'Aspects of Twelfth-Century Byzantine Kaiserkritik', Speculum 58, pp. 326-346, https://doi.org/10.2307/2848257.

Magdalino P., 2000, 'The Pen of the Aunt: Echoes of the Midtwelfth Century in the Alexiad', [in:] Anna Komnene and Her Times, T. Gouma-Peterson (ed.), New York - London, pp. 15-43, https://doi.org/10.4324/9780203765234-2.

Magdalino P., 2002, 'The Medieval Empire 780 - 1204', [in:] The Oxford History of Byzantium, C. Mango (ed.), Oxford, pp. 169-208.

Magdalino P., 2008, 'The Empire of the Komnenoi (1118-1204)', [in:] The Cambridge History of the Byzantine Empire c. 500-1492, J. Shepard (ed.), Cambridge, pp. 627-663, https://doi.org/10.1017/CHOL9780521832311.024.

Magdalino P., 2012, 'Byzantine Historical Writing, 900 - 1400', [in:] The Oxford History of Historical Writing, vol. II. 400-1400, S. Foot, Ch.F. Robinson (eds.), Oxford, pp. 218-237.

Maisano R., 1985, 'Il problemo della forma letteraria nei proemi storiografici Bizantini', Byzantinische Zeitschrift 78, pp. 329-343, https://doi.org/10.1515/ byzs.1985.78.2.329. 
Mango C., 1984, 'Byzantine Literature as a Distorting Mirror', [in:] C. Mango, Byzantium and Its Image. History and Culture of the Byzantine Culture and Its Heritage, London, pp. 3-18.

Marincola J., 1997, Authority and Tradition in Ancient Historiography. Cambridge, https://doi.org/10.1017/CBO9780511584831.

Marincola J., 2007: ' $\dot{\alpha} \lambda \hat{\eta} \theta \varepsilon ı \alpha$ ', [in:] Lexicon Historiographicum Graecum et Latinum II, C. Ampolo, U. Fantasia (eds.), Pisa, pp. 7-29.

McKitterick R., 2000, The Uses of the Past in Early Medieval Europe, Cambridge.

Momigliano A., 1966, 'Time in Ancient Historiography', History and Theory 6, pp. 1-23, https://doi.org/10.2307/2504249.

Mullett M., 1990, 'Dancing with Deconstructionists in the Gardens of the Muses: New Literary History vs?', Byzantine and Modern Greek Studies 14, pp. 258-275, https://doi.org/10.1179/byz.1990.14.1.258.

Murphy J., 1981, Rhetoric in the Middle Ages. A History of Rhetorical Theory from Saint Augustine to the Renaissance, Berkeley - Los Angeles.

Németh A., 2018, The Excerpta Constantiniana and the Byzantine Appropriation of the Past, Cambridge, https://doi.org/10.1017/9781108529068.

Neville L., 2012, Heroes and Romans in Twelfth-Century Byzantium. The Material for History of Nikephoros Bryennios, Cambridge, https://doi.org/10.1017/ CBO9780511933967.

Neville L., 2013, 'Lamentation, History, and Female Autorship in Anna Komnene's Alexiad', Greek Roman and Byzantine Studies 53, pp. 192-218.

Neville L., 2014, 'The Authorial Voice of Anna Komnēnē', [in:] The Author in Middle Byzantine Literature. Modes, Functions, and Identities, A. Pizzone (ed.), Berlin - Boston 2014, pp. 263-274.

Neville L., 2016, Anna Komnene. The Life and Work of a Medieval Historian, Oxford, https://doi.org/10.1093/acprof:oso/9780190498177.001.0001.

Neville L., 2018, Guide to Byzantine Historical Writing, Cambridge, https://doi. org/10.1017/9781139626880.

Neville L., 2019, 'Pity and Lamentation in the Authorial Personae of John Kaminiates and Anna Komnene', [in:] Emotions and Gender in Byzantine Culture, S. Constantinou, M. Meyer (eds.), Cham, pp. 65-92, https://doi. org/10.1007/978-3-319-96038-8_3.

Neville L., Vilimonović O., 2019, Structure and Features of Anna Komnene's Alexiad. Emergence of a Personal History, Amsterdam, https://doi. org/10.5040/9789048551262. 
Nicolai R., 2007, 'The Place of History in the Ancient World', [in:] A Companion to Greek and Roman Historiography, vol. I, J. Marincola (ed.), Malden - Oxford 2007, pp. 13-26.

Nikulin D., 2015, 'Memory in Ancient Philosophy', [in:] Memory. A History, D. Nikulin (ed.), Oxford, pp. 35-84, https://doi.org/10.1093/ acprof:oso/9780199793839.003.0002.

Nilsson I., 2006, 'To Narrate the Events of the Past: On Byzantine Historians and Historians on Byzantium', [in:] Byzantine Narrative. Papers in Honour of Roger Scott, J. Burke (ed.), Leiden - Boston 2006, pp. 47-58, https://doi. org/10.1163/9789004344877_004.

Nilsson I., 2014, 'Komnenian Literature', [in:] Byzantine Culture. Papers from the Conference 'Byzantine Days of Istanbul', May 21-23 2010, D. Sakel (ed.), Ankara, pp. 121-131.

Nilsson I., Scott R., 2007, 'Towards a New History of Byzantine Literature: The Case of Historiography', Classica et Mediaevalia 58, pp. 319-332, https://doi. org/10.4324/9781351219464-5.

Nisbet R.G.M., Rudd N., 2004, A Commentary on Horace's Odes III. Oxford.

Olsen B., 2018: 'Jak rzeczy pamiętają', [in:] Antropologia pamięci, R. Chymkowski et al. (eds.), Warszawa, pp. 85-96, https://doi.org/10.31338/ uw.9788323533627.pp.85-96.

Ostrogorsky G., 1989, History of the Byzantine State, transl. J.M. Hussey, Oxford. Papaioannou S., 2017, 'Rhetoric and Rhetorical Theory', [in:] The Cambridge Intellectual History of Byzantium, A. Kaldellis, N. Siniossoglou (eds.), Cambridge, pp. 101-112, https://doi.org/10.1017/9781107300859.007.

Papalexandrou A., 2010, 'The Memory Culture of Byzantium', [in:] A Companion to Byzantium, L. James (ed.). Malden - Oxford - Chichester, pp. 108-122, https://doi.org/10.1002/9781444320015.ch9.

Partner N.F., 1986, 'Making Up Lost Time: Writing on the Writing of History', Speculum 61, pp. 90-117, https://doi.org/10.2307/2854538.

Patlagean E., 1987, 'Byzantium in the Tenth and Eleventh Centuries', [in:] A History of Private Life, vol. I, P. Veyne (ed.). Cambridge Mass. - London, pp. 551-639.

Phillips J., 2019, 'Crusader Perceptions of Byzantium, c. 1095 - c. 1150', [in:] Byzantium and the West. Perception and Reality $\left(11^{\text {th }}-15^{\text {th }} \mathrm{c}.\right)$, N.G. Chrissis, A. Kolia-Dermitzaki, A. Papageorgiou (eds.), Abindgon - New York, pp. 102-117, https://doi.org/10.4324/9781315163390-7. 
Pratsch T., 2005, Der hagiographische Topos. Griechische Heiligenviten in mittelbyzantinischer Zeit, Berlin - New York, https://doi.org/10.1515/9783110912715.

Quandahl E., Jarratt S.C., 2008, “To Recall Him ... Will be a Subject of Lamentation': Anna Comnena as Rhetorical Historiographer', Rhetorica 26, pp. 301335, https://doi.org/10.1525/rh.2008.26.3.301.

Reinsch D.R., 2001, 'Einleitung', [in:] Anna Komnene, Alexias, ed. D.R. Reinsch, Berlin, pp. 8-18, https://doi.org/10.1515/9783110867626-002.

Riley-Smith J., 2003, First Crusade and the Idea of Crusading, Philadelphia.

Rosenqvist J.O., 2007, Die byzantinische Literatur. Vom 6. Jahrhundert bis zum Fall Konstantinopels 1453, Berlin - New York, https://doi. org/10.1515/9783110912319.

Runciman S., 1951, A History of the Crusades, vol. I. The First Crusade and the Foundation of the Kingdom of Jerusalem, Cambridge.

Runciman S., 1966, Byzantine Civilization, London.

Savvides A.G.C., Hendrickx B., 2001, Introducing Byzantine History (A Manual for Beginners), Paris.

Scott R., 2010, 'Text and Context in Byzantine Historiography', [in:] A Companion to Byzantium, L. James (ed.), Malden - Oxford - Chichester, pp. 251262, https://doi.org/10.1002/9781444320015.ch19.

Shawcross T., 2018, 'Introduction I: Byzantium: A Bookish World', [in:] Reading in the Byzantine Empire and Beyond, T. Shawcross, I. Toth (eds.), Cambridge, pp. 3-35, https://doi.org/10.1017/9781108289993.

Small J.P., 1997, Wax Tablets of Mind. Cognitive Studies of Memory and Literacy in Classical Antiquity, London - New York.

Sorabji R., 1972, Aristotle on Memory, London, https://doi.org/10.5040/97814 72598110.

Spiegel G.M., 1997, The Past as Text. The Theory and Practice of Medieval Historiography, Baltimore - London.

Stanković V., 2011, 'Lest We Forget: History Writing in the Byzantium of the Komnenoi and the Use of Memories', [in:] Memory and Oblivion in Byzantium, A. Milanova, V. Vatchkova, T. Stepanov (eds.), Sofia, pp. 59-65.

Stemplinger F., 1913, Das Plagiat in der griechischen Literatur, Leipzig - Berlin 1913.

Tod M.N., 1948, A Selection of Greek Historical Inscriptions, vol. II. Oxford.

Treadgold W., 2013, The Middle Byzantine Historians, New York, https://doi. org/10.1057/9781137280862. 
Vidal-Naquet P., 1996, 'Divine Time and Human Time', [in:] P. Vidal-Naquet, The Black Hunter. Forms of Thought and Forms of Society in the Greek World, Baltimore - London, pp. 39-60.

Vryonis Jr. S., 1967, Byzantium and Europe, London.

Walker J., 2001, 'Michael Psellos on Rhetoric: A Translation and Commentary on Psellos' Synopsis of Hermogenes', Rhetoric Society Quarterly 31, pp. 5-40, https://doi.org/10.1080/02773940109391193.

Whitehead A., 2009, Memory, Abingdon - New York, https://doi. org/10.4324/9780203888049.

Wilson N.G., 1975, 'Books and Readers in Byzantium', [in:] Byzantine Books and Bookmen, C. Mango, I. Ševčenko (eds.). Washington DC, pp. 1-15.

Wilson N.G., 1996, Scholars of Byzantium, London - New York.

Woodman A.J., 1988, Rhetoric in Classical Historiography. Four Studies. London - New York.

Zakrzewski K., 2007 (1938¹), Historia Bizancjum, Kraków. 